デジタルマンモグラフィーソフト診断の応用(1)

\title{
1 台のマンモビューワによる多種のデジタルマンモグラフィ読影診断の可能性
}

国立病院機構 名古屋医療センター放射線科

遠藤登喜子 大岩 幹直 吉川 和明 森田 孝子

1 台のマンモビューワに多種類のデジタルマンモグラフィと乳房超音波画像を接続し， 問題点と弚の解決法, マルチモダリティによる診断の有用性を検討した。マンモグラフィ 画像観察装置は, 東芝メディカルシステムズH/W : TDV-7000, マンモビューワは S/ W : STWS-005，画像保管・配信サーバはTFS-7000 R を用い，2室の乳房撮影室に設置され ている富士，コニカ，ケアストリームヘルスの 4 種の CR と，外科外来と放射線科超音波 室に設備されている東芝, アロカ, 日立の 4 種類の超音波診断装置を放射線科サーバ室の サーバと接続 ,ビューワは外科外来と放射線科超音波室に設備・接続した。問題点として， 1)DICOM 規格の CR 登録と M G 登録の違いによるトラブル , 2)別患者・別検査が同一の 検査UID で出力された，3)DICOM メディアの読込みエラー，4)メーカ別のリスト表示 の不統一，5)拡大撮影のスケール表示の不正確，6)技師名表示がない，7)画像観察条件が 不十分，などが明らかとなった。いまだ解決されていない問題点もあるが, 各社 DICOM 画像を1台のマンモビューワで読影することは十分可能であった。また，超音波画像をモ ニタに表示したことによって, 乳房超音波診断手技上の改良点が発見でき, マンモグラフ イを中心とした乳房画像総合診断が機能的に実施できるようになった。今後，よりストレ スの少ないモニタ診断を実現できるよう，さらなる改良を期待したい。

Key words : マンモビューワ , マルチモダリティ, デジタルマンモグラフィ, DICOM , モニ 夕診断

はじめに

最近のデジタルマンモグラフィの進歩は目を見 張るものがある。日本では CR によるデジタルマ ンモグラフィが開発された歴史があるが, モニタ などの観察機器がマンモグラフィ診断には不十分

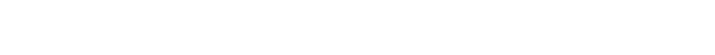
焼付けして診断されてきだ2)。しかしながら，他 の画像診断のフィルムレス化, コンピュータの進 歩による画像処理・転送の高速化, モニタの進歩 などにより，マンモグラフィでもモニタ診断が可

別冊請求先 : † 460-0001 名古屋市中区三の丸 4-1 -1 国立病院機構 名古屋医療センター 放射線科 遠藤登喜子

E-mail address : endot@nnh.hosp.go.jp
能となってきている。日本におけるデジタルマン モグラフィの歴史の長さから，一施設に数社のデ ジタル装置が設置されている環境も珍しくはな い。当院では受託研究により 1 台のマンモビュー ワに多種のデジタルマンモグラフィを接続し , 読 影診断を可能としたので, 乥の使用経験を報告す る。なお, 正式な診療の運用はハードコピーで行 っており, 読影の精度管理のために 1 週間分のマ ンモグラフィを部内マンモグラフィ関係者全員で まとめて読み直してみる「読み合わせ会」では, 両者の対比も行っている。

\section{1. 研究の目的}

1 台のマンモビューワに多種類のデジタルマン モグラフィを接続し , 明らかになった問題点に対 して光の解決法を検討し, 加えて今後のソフトコ 
ピー診断の課題を明らかにする。また，乳房超音 波画像等, 他の画像も接続し, マルチモダリティ による診断の有用性を検討する。

2. 使用機器と評価法

マンモグラフィ画像観察装置は東芝メディカル システムズH/W :TDV-7000で, マンモビューワ はS/W : STWS-005,画像保管・配信サーバは東 芝メディカルシステムズTFS-7000R である。モ ニタは $5 \mathrm{MP}$ モノクロで, アンチグレア処理なし で, 500cd $/ \mathrm{m}^{2}$ の輝度, 階調はDICOM Part $14^{34}$ に準じたものである。本装置に接続したデジタル
マンモグラフィ装置は，次の3社の4装置で , す ベて CR である(表 1)。コニカミノルタヘルスケ ア社の M ermaid(東芝メディカルシステムズ M GU100B にPCM システムを装備)は1画素25 $\mu \mathrm{m}$ 相当, シーメンス社マンモマート 3000 で撮影 され, Regius M odel 190で処理される CR は読み 取りピッチ43 .75 $\mu \mathrm{m}$, 富士フイルムメディカル Profect CS は50um ，ケアストリームヘルス Direct View CR 850は48 5 $\mu \mathrm{m}$ で, データ量の目安を表 2 に示す。接続は図 1 に示すように, 各画像処理装 置をサーバに, サーバと外科外来と放射線科超音 波検査室に置かれた 2 台のマンモビューワを接続

表 1. マンモビューワへの接続機器

\begin{tabular}{|c|c|c|c|}
\hline 種別 & & メーカ名 & 機器名 \\
\hline マンモグラフィ画像ビューワ & & 東芝メディカルシステムズ & $\begin{array}{l}\text { H/W : TDV-7000 } \\
\text { マンモビューワ S/ W : } \\
\text { STWS-005 }\end{array}$ \\
\hline 画像保管・配信サーバ & 1 & 東芝メディカルシステムズ & TFS-7000R \\
\hline マンモグラフィ撮影装置 & 1 & $\begin{array}{l}\text { コニカミノルタヘルスケア } \\
\text { コニカミノルタヘルスケア } \\
\text { SIEMENS } \\
\text { 富士フイルムメディカル } \\
\text { SIEMENS } \\
\text { ケアストリームヘルス } \\
\text { SIEMENS ※接続計画中 }\end{array}$ & $\begin{array}{l}\text { REGIUS Vstage M ODEL } \\
190 \\
\text { M ERM AID }(25 \mu) \\
\text { REGIUS Vstage M ODEL } \\
190(43.75 \mu) \\
\text { M AM M OM AT } 3000 \\
\text { FCR PROFECT CS }(50 \mu) \\
\text { M AM M OM AT } 3000 \\
\text { DirectViewCR850 }(48.5 \mu) \\
\text { M AM M OM AT } 3000\end{array}$ \\
\hline
\end{tabular}

表 2. マンモグラフィの画像データ量

\begin{tabular}{l|l|c|c|c}
\hline メーカ & 装置名称 & $\begin{array}{l}\text { サンプリング } \\
\text { ピッチ }\end{array}$ & $\begin{array}{l}\text { イメージマトリ } \\
\text { ックス(pixels) }\end{array}$ & $\begin{array}{c}\text { データ } \\
\text { 量(MB })\end{array}$ \\
\hline $\begin{array}{l}\text { コニカミノルタ } \\
\text { ヘルスケア }\end{array}$ & MERM AID & $25 \mu$ & $9480 \times 6880$ & 約130 \\
$\begin{array}{l}\text { 富士フイルム } \\
\text { メディカル }\end{array}$ & $\begin{array}{l}\text { FCR } \\
\text { PROFECT }\end{array}$ & $50 \mu$ & $4740 \times 3540$ & 約33 \\
\hline CS & & & \\
(比較例) & $\begin{array}{l}\text { Senographe } \\
\text { GE }\end{array}$ & $100 \mu$ & $2294 \times 1914$ & 約 8 \\
\hline
\end{tabular}

※ 5 M モニタの解像度 : $2560 \times 2048$ 


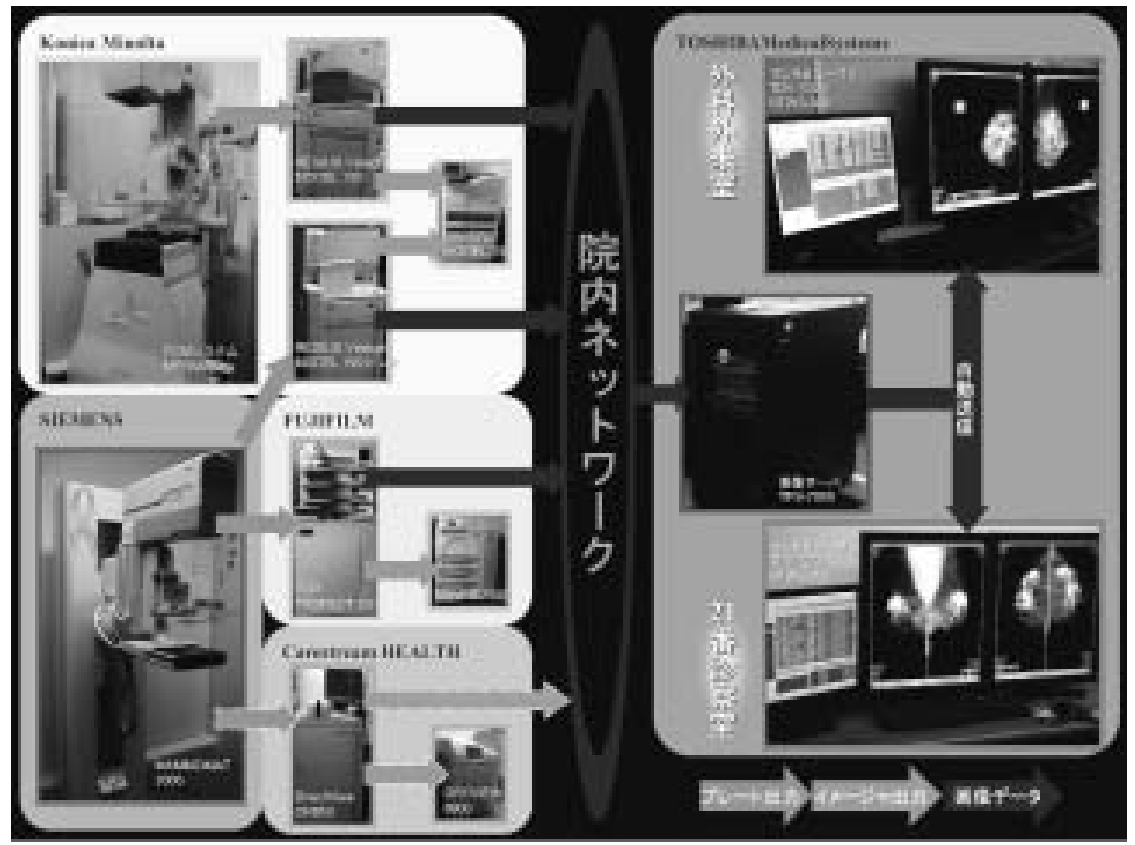

図 1. マンモグラフィの自動配信ネットワーク

表 3. 他院デジタルマンモグラフィの画像読込み実績

\begin{tabular}{l|l}
\hline メーカ & 装置名称 \\
\hline GE & Senographe 2000D \\
日立メディコ & LORAD Selenia \\
島津製作所 & SEPIO NUANCE \\
東芝メディカルシステムズ & M AM M OREX Pe·ru·ru \\
コニカミノルタヘルスケア & M ERM AID (PCM システム) \\
シーメンス & NOVATION \\
\hline
\end{tabular}

し，自動配信ネットワークを作成した。

また , 表 3 に示す他のデジタルマンモグラフィ (フラットパネルの全機種およびPCM 画像)デー 夕を, 他病院の研究協力者から DICOM メディア で提供していただき，ビューワに読込み，正常に 画像表示できるかを確認した。

超音波装置はマンモビューワを設置した外科外 来と放射線科検査室に設置されており，これをサ 一バに接続した。超音波検査は，原則として，乳 腺外来を受診された外来患者を対象として即日行 うが，超音波検査に際しマンモグラフィ読影診断 を行っている。接続した超音波診断装置は，東芝 メディカルシステムズAplio XG SSA-790A およ びAplio SSA-770A, 日立メディコ EUB-8500と

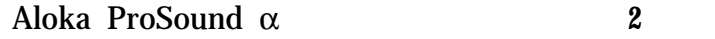
す。

3. 結 果

1)マンモグラフィの接続と診断に関する知見

デジタルマンモグラフィ・CR 4 機種を 1 台の マンモビューワに接続したことによって，いくつ かの問題点が明らかとなった。が，順次，乥れ光 れに対応することによって日常診療にまったく問 題なく使用できるようになった。

代表的な問題点と光の原因を示す。

1)画像がMG で出力されない。

原因：DICOM 規格には，MGの規格には存在 するモジュールの中には $C R$ 規格ではないものが 


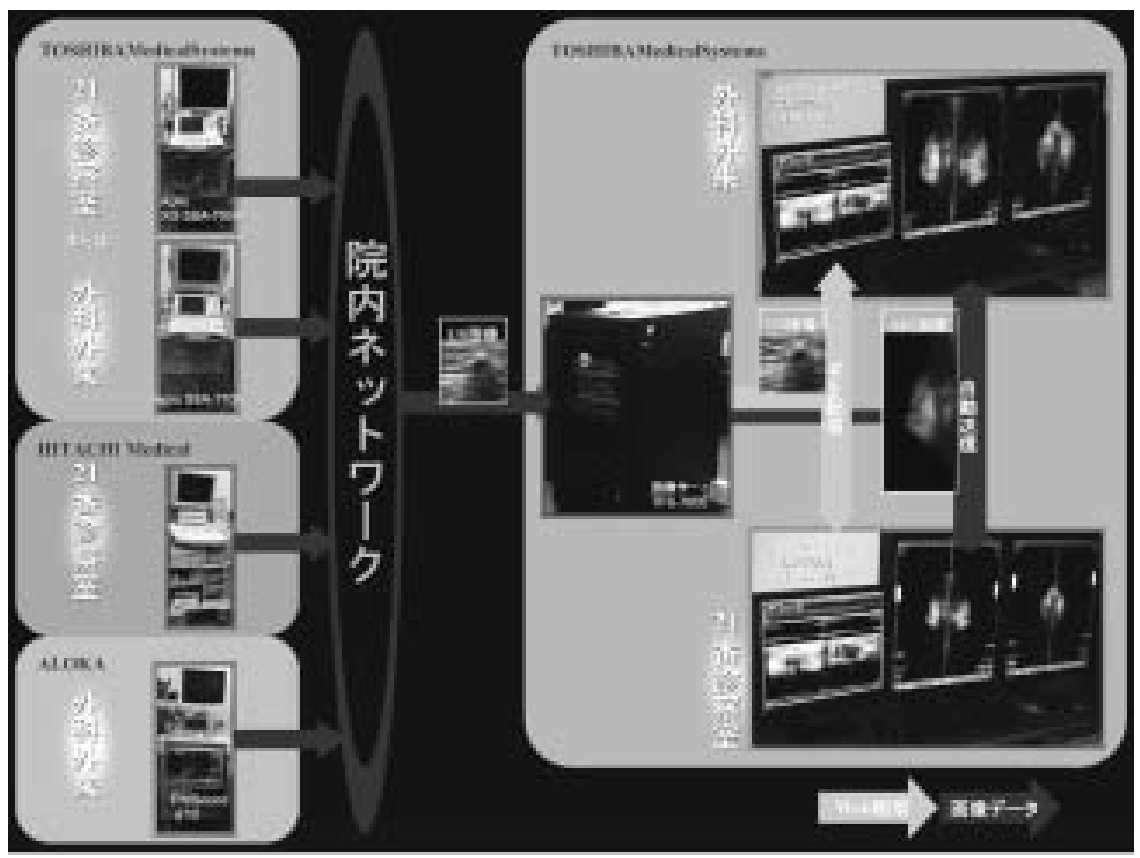

図 2. 乳房超音波画像の配信ネットワーク

ある。MG として登録せず，CR として撮影され ていたため, マンモグラフィとしての表示ができ なかった。

対策 : 撮影時の画像登録を正しく行う。但し， 患者ごとにこの作業を意識的に行わなくてはなら ないことは人為的ミスにつながる問題で , マンモ グラフィ装置から転送される情報はマンモグラフ イとして自動登録されることが必要である。

2)撮影したはずの患者の画像が見つからない。

原因：別患者・別検査であるのに，同一の検査 UID で検査が出力されたため, 画像サーバが光 の検査を受信できなかった。

対策 : 登録システムの整備

3)DICOM メディアの読み込みエラー

原因 : DICOM 規格に(完全には)準じていない メディアのため，読込みできなかった。

対策 : 各社, DICOM 規格での情報の作成を徹 底する。

4)リスト表示で, 患者名の表示が漢字・カナの混 在したものとなった。

原因 : 装置メーカの規格が統一されたものでな い。
対策 : HIS-RIS の接続および装置での表示は， ユーザの希望で漢字 , カナ, アルファベット表示 を選択し , 統一した表示法か望まれるが, 現在も 表示は各装置によって異なっている。

5)スケールが正しく表示されない(図 3)。

原因：拡大撮影では，CR 画像に拡大率が伝達 できていないため, 密着撮影と同じスケールで表 示されてしまう。

対策：撮影装置から CR 装置に拡大率を伝達で きるシステムを開発することであるが, 撮影装置 と画像処理装置の情報交換システムが必要なた め, この問題はまだ解決されていない。

6)技師名の表示がない。

原因：撮影技師名がDICOM のプライベートタ グに格納されていた。关のほか, 技師が自分の氏 名の入力をしないで撮影してしまう場合も考えら れる。

対策 : 表示可能部に移動させた。技師には，撮 影者の氏名入力が当然とする教育を徹底すること が必要である。

7)画像の見たい部分 (スキンラインや脂肪濃度内情 報など)がみえない。全体的に暗く見える。フィル 


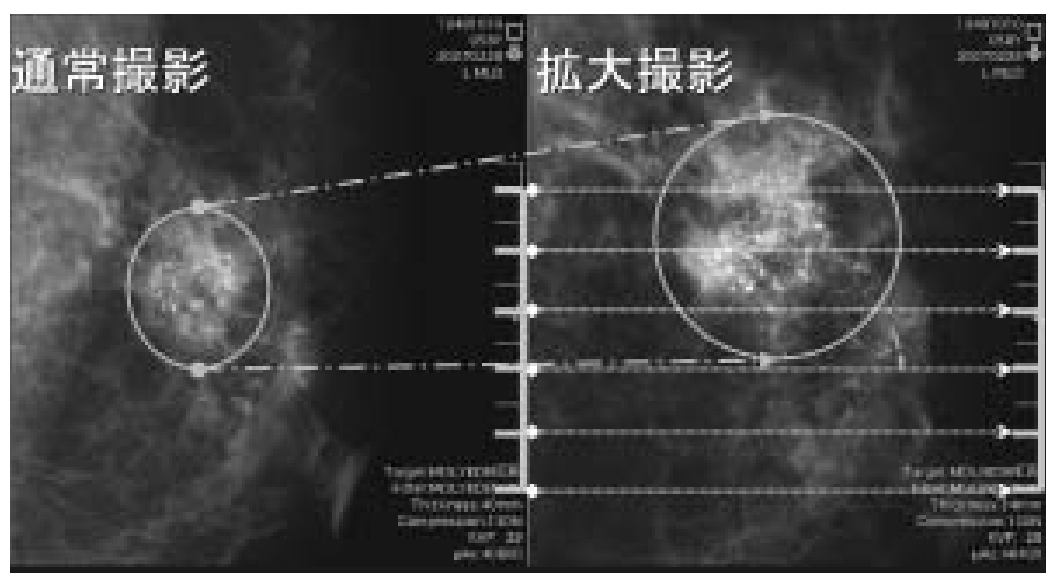

図 3. 通常撮影と拡大撮影. 表示スケールが正しく表示されていない.

ムでの見え方と違いすぎるなど, 階調変更しても 十分に観察できない。

原因：raw dataから DICOM にする段階で，画 像処理情報が欠落する。

対策 : 各メーカでの画像処理を変更し，画像処 理のLUT を添付した。しかし，メーカごとに画 質は大きく異なっている。

以上 , 接続上の問題点が明らかになったが , 現 在 , 各社のデジタルマンモグラフィのDICOM 画 像を 1 台のマンモビューワで読影診断することが できている。PCM 画像(一画像あたり約130M B ) の画像表示も 4 枚あたり 9 秒程度で可能で, 診療 上ではまったく問題ない速度が実現されている。

\section{2) 超音波診断装置との接続}

各社の超音波装置との接続は, デジタル装置で あったことから特に問題なく実施可能であった。 データはサーバに転送され，1MP モニタへの表 示も大きな問題はなく行われた。が, 次のことが 明らかとなった。

超音波装置からサーバへの転送は, 装置のハー ドディスクへの記録した画像毎に転送する場合 と，検査が終了したあとで転送する場合の選択が 可能で, 超音波装置の固定場所での稼動とポータ ブルでの稼動に対応できた。ポータブル装置とし て搬出した場合には，検査後にまとめて転送する
ことになるが, 当院を含め超音波画像については 管理責任者が明瞭でない施設が多く，転送作業を 誰が行うかなど 新たな問題が出現した。さらに, 1 枚毎の転送では，ケーブルの接続端子が不安定 で，ときにDICOM ERRORが超音波モニタに出 現し, 検査が中断した。接続部分を頻回に脱着さ せることが，接続不十分な状況を作り出す原因で はあったが, 特に超音波検査では装置の持ち出し は通常に行われる医療行為であり，これを考慮し た安全な接続が必要である。

問題点として，乳房超音波検査では，ドプラ検 査, エラストグラフィや微細石灰化検出のための 「micro pure」など，動画を使う機会が増えてい るが, 今回の研究で用意したのは静止画サーバで あり, 動画に対応できないことが挙げられた。こ れを解決するには, 動画サーバの設置・接続が必 要である。

\section{4. 考 察}

今回 , マンモビューワに多種のデジタルマンモ グラフィを接続, あるいはデータ入力を行ったこ とにより読影診断が可能であることが確認され た。今回撮影されたマンモグラフィのモニタによ る診断が遅滞なく行えることが確認できたこと以 外にも，いくつかのメリットが存在することが明 らかとなった。 


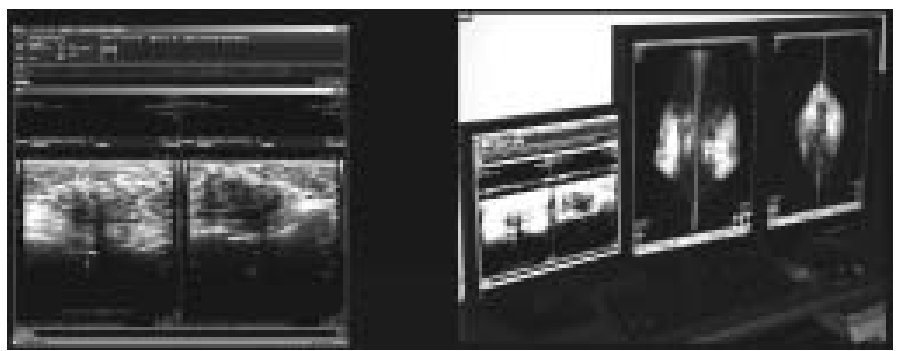

図 4. マンモグラフィ読影におけるマルチモダリティ環境

マンモ用の同一サーバに保存された超音波画像がWeb にて観察 可能で, 超音波検査で撮影した断層像を撮影位置順に並べて表示 し , マンモグラフィ画像とともに一覧できる . 高精細のマンモビュ 一ワを中心として，多種の画像を同時に観察することにより総合診 断が容易となり，診断効率・質の向上に有用である．

そのメリットをあげると，

1)各デジタルマンモグラフィメーカの専用ビュ 一ワを揃える必要がない。关のことによって，2) 設置経費が少なくてすみ，3)ビューワ操作の習得 は1台分のみですむ。

さらに，4)各社のデジタルマンモグラフィ画像 の特性や差異を確認することができたことも画像 を考察する上では大きなメリットであった。

しかしながら，各社の画像特性が異なること は, 読影診断医の立場からみると，画像毎に診断 基準を変更する必要があるということでもある。 また，比較読影で同一モニタに異なったメーカの 画像を表示した場合，観察しにくいなどの問題点 が出現した。比較読影を基本とするマンモグラフ イの読影診断では，各社の画像がほぼ同樣の画質 であること，关れもモニタ機能にあった画質基準 である必要があると考えられる。

各社の画像作成は，現在のところ，各社画像作 成者の考えによって異なっていると考えられる が, 皮膚・脂肪組織内情報が読みやすい latitude の広い(全体に白っぽい)画像を初期表示するメー カと, 乳腺内コントラストが高いが脂肪組織内情 報が乏しい画像を表示するメーカ，さらに，皮膚 も脂肪組織内の線維も厚い乳腺もコントラストな く全体を表示するメーカもあり，画像コントラス 卜的には問題が残るものである。光れは，モニタ
という画像表示装置の濃度表示能がフィルム (デ ジタル用フィルムを含む)の性能に追いつかない ことによるもので ${ }^{2)}$, 今後改良すべき最大の課題 である。

次に，マルチモダリティ画像を総合的に読影・ 診断することが乳癌の診断でも必要であるが，今 回，超音波画像を1M モニタに表示したことに よって，乳房超音波診断を行う上での大きな改良 点を発見することができた。すなわち，モニタに は 2 画像を並べて表示するため, スキャン時に連 続するよう多少の工夫をすることで, 乳房の断面 のほぼ全体を見ることができるようになった (図 4)。断面の全体像を見ることにより，超音波 診断でも, 乳房・乳腺全体の中における病変の位 置づけ, 乳腺の状態を客観的な背景として参考に しながら診断すること, 病変の(区域性)分布を容 易に考慮することができるようになった。以後， ビューワに2枚の超音波画像が並んで表示される ことを前提に, 検査の位置や方向，順番など，超 音波の走査法に工夫を加えている。

さらに, マンモグラフィの見直し会・症例検討 会を機能的に実施できるようになったことも大き なメリットである。5M モニタにはマンモグラ フィを，1Mモニタには超音波画像を表示し， 両画像を同時に読影・診断できることにより，多 くの症例を短時間で総合討論することが可能とな 
つた。フィルムを持ちに行く必要はなく，時間を 節約することができたのも日常業務として見直し 会の運営に大きく貢献している。

しかし，モニタ診断については，まだ解決すべ き課題も少なくない。従来, フィルムで読影診断 を行ってきた効率と精度を落とさないということ は最低限の要求であるが, この点はまだ十分に満 たされていないということである。

診断効率を落とさない画像表示としては, 現ビ ユーワでも，130M B の画像でも精密検査に耐え うる十分な表示速度を維持しているが, 今後, 検 診マンモグラフィの読影のように多くの症例を読 影するのにストレスのない表示速度が必要であ り, しかも, 過去画像も含めた複数検査の表示. 比較読影が必要である ${ }^{5}$ ということである。精度 としては，1画像で全画素の情報を確認できる超 高精細モニタを実現できれば，「拡大してようや く発見できる石灰化」を拡大しないために見落と すことはなくなる。130M B の大きな画像でも , 100\%にてフィット表示されるよう，5ＭPより もさらに高精細なモニタ(超高精細モニタ)の開発 か望まれる。また，現状では，モニタの画面の大 きさと数に表示できる画像数が制限されている が, 過去画像の比較を borderless $2 \times 2$ の 4 面サ イズに配置 , シャウカステンを使う感覚での読影 (自由度)が可能になればストレスは少なくなる。 そして, 最終的には, 難しいデジタル技術や設定 内容を知らなくても高画質の画像が見られ，メー カに限定されることなく，どこでもアナログより 進歩したことを実感できるシステムにまで高めら
れることが望ましいと考える。

$$
\text { おわりに }
$$

1 台のマンモビューワに多種のデジタルマンモ グラフィを接続し，あるいはデータを読み込むこ とにより，読影診断を可能とすることができた。 接続時, 各メーカのDICOM 出力にはさまざまな 問題点が存在することが明らかとなったが, 問題 点の解決により, デジタルマンモグラフィのソフ トコピー診断には選択の自由度が増加したと思わ れる。加えて，マンモビューワを中心として多種 の画像をまとめて読影できるマルチモダリティ環 境が構築でき, 効率的に乳房の総合画像診断を行 うことが可能となった。今後, よりストレスの少 ないモニタ診断を実現できるよう，さらなる改良 を期待したい。

\section{【文 献】}

1) 西 嘉一: 各種モニタの現状 種類・性能とマ ンモグラフィ表示. 映像情報 , 37 : 1206-1211， 2005

2 ) 早乙女 滋 : デジタルマンモグラフィのハード コピーシステム . 映像情報 ,37 : 1196-1201,2005

3) 日本医用画像管理学会編: 医用画像情報管理パ ーフェクトブック. 日本放射線技師会出版会, 2007

4 ) DICOM 日本語公式ページ : http : / / www.jfcr.or. jo/DICOM/

5 ) 日本医学放射線学会/日本放射線技術学会編: マ ンモグラフィガイドライン. 第2 版(増補版), 医学書院, 東京, 2007 


\title{
Investigation of the Breast Image Viewing System Which Can Develop Many Different Kinds of Digital Mammography
}

\author{
Tokiko Endo, Mikinao Oiwa, Kazuaki Yoshikawa, Takako Morita \\ D epartment of R adiology, $\mathrm{N}$ ational $\mathrm{H}$ ospital O rganization $\mathrm{N}$ agoya M edical $\mathrm{C}$ enter
}

We reported the investigation of the breast image viewing system, which has indicated many different kinds of digital mammography. The system is composed of Toshiba Medical Systems H/W : TDV-7000, S/W : STWS-005 and TFS-7000R. Four different CR systems and four different ultrasonography units were connected to this system. Following problems have rise to the surface ; 1 ) the registration errors of the image type; although it must be registered as MG image, registered as CR image, 2)the output errors using a same examination UID for different patient or different examination, 3)the reading errors from the DICOM media, 4)the inharmonious display of the patients list using different characters for each manufactures, 5) the incorrect scale indication on the magnified photography, 6)the loss of the representation of the technologist's name, 7) the image quality insufficiency for reading diagnosis. Some problems are resolved and usual image interpretation of many kinds of diagnostic mammography can be performed now without any obstacles. The two direction four sheets mammography taken by PCM system, which has about 130 MB data for each one sheet can be developed within about nine seconds. Moreover, by the breast ultrasonographic images have been indicated on the monitor every two sheets, we can refine the breast scanning way. And very swift and functional multi-modality diagnosis has been realized in the conference using this breast image viewing system. Hereafter, more improvements of the system are expected.

Key words: digital mammography, breast image viewing system, DICOM 